\title{
Does functional assessment of individuals aged 80-plus give rise to scientific discussion - considerations based on literature review
}

\author{
Mariola Głowacka ${ }^{1, A-D, F}$, Paulina Zabielska ${ }^{2, B-D}$, Beata Haor ${ }^{3, B-D}$, Beata Karakiewicz 2,E-F \\ ${ }^{\prime}$ Laboratory of Clinical Skills and Medical Simulation, Ludwik Rydygier Collegium Medicum, Bydgoszcz, Nicolaus \\ Copernicus University, Toruń, Poland \\ ${ }^{2}$ Department of Social Medicine and Public Health, Chair of Social Medicine, Pomeranian Medical University in Szczecin \\ Poland \\ ${ }^{3}$ Department of Neurological and Neurosurgical Nursing, Ludwik Rydygier Collegium Medicum, Bydgoszcz, Poland \\ A - Research concept and design, B - Collection and/or assembly of data, C - Data analysis and interpretation, \\ $D$ - Writing the article, $E$ - Critical revision of the article, $F$ - Final approval of article
}

Głowacka M, Zabielska P, Haor B, Karakiewicz B. Does functional assessment of individuals aged 80-plus give rise to scientific discussion considerations based on literature review. Ann Agric Environ Med. 2019; 26(2): 375-378. doi: 10.26444/aaem/86458

\begin{abstract}
Introduction and objective. For many years, Europe has been struggling with the problem of an aging society. It is obvious that everyone would like to live longer while retaining good psycho-physical health and social activity. This, however, is influenced by many factors, such as health, which may be a form of limitation in everyday life or in performing social roles in accordance with the norms.

Objective. The aim of the study was to analyze the use of scales for functional assessment of basic and complex daily living activities in individuals aged $80+$ in various EU countries.

Materials and method. Potentially essential articles were obtained through review and analysis of the PUBMED (MEDLINE) database by entering the following keywords: functional activities of daily living, $A D L, I A D L$, complex activities of daily living, basic activities of daily living. Article selection was based on the following inclusion criteria set by the authors and the appointed Advisory Board.

Results. Assessment of independence and fitness of elderly persons in the area of basic and complex activities of daily living provides information on the quality of life of senior individuals. Analysis of research data used for comparing functional independence of senior persons on the basis of ADL and IADL scales is difficult due to the discrepancies, which may be confusing for researchers studying this area.

Conclusions. The use of different methodologies for assessing functional fitness of elderly individuals makes it difficult to interpret, compare and practically apply the outcomes. Standardization of research methods used for assessment of basic and complex daily living activities in $80+$ persons would enable comparing the obtained data in an interdisciplinary perspective.
\end{abstract}

\section{Key words}

elderly, IADL, ADL, scale analysis

\section{INTRODUCTION}

For many years, Europe has been struggling with the problem of an aging society. Only several decades ago, people aged over 80 years made up a small part of the population. At present, with a decreasing number of births and a growing length of life, the number of elderly individuals is growing at an alarming rate $[1]$.

The European Commission warns that by 2025 , over $20 \%$ of Europeans will have become older than 65 years, whereas an especially large increase has been noted in the group of the 80 -plus [2]. Eurostat predicts that the share of people aged $65+$ in the European Union population (including Poland) will increase from the level of $17.1 \%$, which was recorded in 2008 , to $30 \%$ in 2060 , while for people aged $80+$, there will be an increase from 4.4 to $12.1 \%$ in the same period. On the European continent in recent decades, the

Address for correspondence: Paulina Zabielska, Department of Social Medicine and Public Health, Chair of Social Medicine, Pomeranian Medical University in Szczecin, Żołnierska, 48, 71-210 Szczecin, Poland

e-mail: paulina.zabielska@pum.edu.pl

Received: 25.09.2017; accepted: 09.03.2018; first published: 04.04.2018 population of the newly- accessed member states from central and eastern Europe has been aging faster than in the EU founding countries. This trend is especially noticeable in Baltic countries and in Slovenia. The least beneficial situation regarding population aging is in Italy and Germany. Ireland, on the other hand, is a country with a decrease in the percentage of the elderly in the population $[4,5]$.

Without doubt, the phenomenon of the lengthening of life can be considered a success. Due to an improvement in socioeconomic conditions, health care quality and environmental conditions life expectancy at time of birth increased by an average 10 years in the whole EU [6]. However, it needs to be kept in mind that this also poses a great challenge, which produces not only social but also health and economic consequences. It is forecast that in 2050 there will be two professionally active people per one pensioner compared, to three or four at present. Therefore, long-term care and intergenerational social cohesion are important issues $[5,7]$.

It is obvious that everyone would like to live longer while retaining good psycho-physical health and social activity. This, however, is influenced by many factors, such as health, which may be a form of limitation in everyday life or in 
performing social roles in accordance with the norms $[8$, 9]. An important issue in the process of aging is keeping independence in every aspect of life, especially in the area of basic and complex daily living activities. The functional status of an elderly person can be assessed using the Katz Index of Independence in Activities of Daily Living (ADL), which facilitates assessment of independence in performing such daily activities as: bathing, dressing and undressing, using the toilet, moving in and out of bed or chair, eating, urine and stool passing and continence. The scoring in the ADL scale is $0-6$ points.

Another available tool is the Lawton Instrumental Activities of Daily Living (IADL) Scale which assesses complex daily living activities, among others: ability to use the telephone, to reach places outside a short walking distance, buy food and prepare a meal, to perform basic housekeeping activities, to take medication and to handle finances. The higher the score obtained in both tests, the more fit the assessed person $[10,11,12,13]$.

A low result in the Katz or Lawton scale means a low level of independence or inability to independent functioning, which involves the need for constant assistance of other persons - family members or institutional assistance. Researchers from Europe and worldwide discuss the subject of capability of elderly individuals, therefore the need for examining the standardized research tools of ADL and IADL scales is justified. Interpretation of the obtained results outcomes may be difficult because of the involvement of the use of different research tools.

\section{OBJECTIVE}

The aim of the study was to analyze the use of scales for functional assessment of basic and complex daily living activities in individuals aged $80+$ in various EU countries.

\section{MATERIALS AND METHOD}

Search methods. Potentially essential articles were obtained through review and analysis of the PUBMED (MEDLINE) database by entering the following key words: functional activities of daily living, ADL, IADL, complex activities of daily living, basic activities of daily living. The review also comprised vital research included in the references of the selected articles which met all the inclusion criteria.

Study selection. Article selection was based on the following inclusion criteria set by the authors and the appointed Advisory Board:

1. Articles must have been be published between 01.1997 03.2017.

2. Articles should be written in Polish or English.

3. Research should be conducted in the countries of the European Union.

4. The studied persons should be at least 80 years old.

5. The articles had to contain information on the use of scales for assessment of basic and/or complex daily living activities. 6. There was open access to the articles.

A group interview among specialists dealing with the problem of elderly people was conducted in order to develop

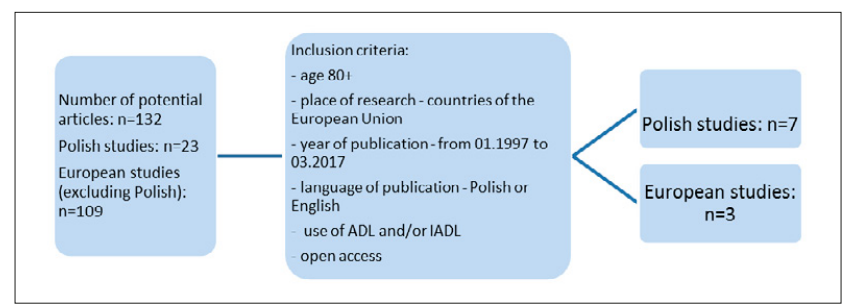

Figure 1. Selection of the literature analyzed in the study [own elaboration]

criteria effective for achieving the aim. A representative of health care, representatives of social assistance, a psychologist and a public health specialist were invited to join the Advisory Board. The stages of literature selection are shown in Figure 1.

One of the criteria was open access to complete article texts, which is especially important in Evidence-Based Medicine and Evidence-Based Nursing Practice. Doctors and nurses, in their everyday clinical practice, seeking scientific evidence in response to clinically relevant questions arising while providing medical services, and formulated according to the so-called PICO framework ( $\mathrm{P}$ - population, I - intervention, $\mathrm{C}$ - comparison, $\mathrm{O}$ - outcome), have unrestricted access to thematic reports. Full accessibility is often very important because of the urgency of patients' medical conditions.

\section{RESULTS}

The study by Jakimowicz and Kostka [14] enrolled 104 residents of a Social Assistance Home in Kalisz, Poland, and included 18 persons at the age of 80.3 . Within the analyzed age range the mean score was $5.5 \pm 0.7$ and $4.3 \pm 2.0$ for ADL and IADL scales, respectively. On the other hand, Kozak-Szkopek and Galus [15], whose research involved 22 female residents of a Health Service Worker Residential Home in Warsaw, Poland, reported higher results. All the studied women were capable of simple activities of daily living. Six residents used walking supportive equipment (walking stick, walking frame). They also needed assistance with some complex activities of daily living. Interpretation of the results based on arithmetic mean was also applied by Mossakowska et al. [16]. The scoring in the IADL scale (11.5) was in the range of the results obtained by Jachimowicz and by Kozak-Szkopek, despite a much lower mean age of the respondents - 101.4.

Biercewicz [17] studied 127 Geriatric Clinic patients of the A. Jurasz University Hospital No. 1 in Bydgoszcz, Poland, hospitalized do to a diagnosed disease process. This group included 6 individuals aged 90 years and over, as well as 81 patients aged 75-89. The results were only obtained for the basic activities of daily living scale and reached the mean level of 4.89. Unfortunately, the outcomes did not distinguish respondents aged $80+$, therefore this result could not be included in the comparative analysis.

Puzio et al. [18], due to the lack of normal distribution of ADL and IADL scoring, applied a median measure for statistical description. Patients aged 8 , who had undergone a hip endoprosthesis procedure, scored 5 and 18 points for ADL and IADL, respectively, in self-assessment of simple and complex daily living activities. In ADL, the patients indicated the biggest problems with bathing (45\%) and urine and stool continence (39\%), while in IADL, housekeeping activities (36\%) and shopping (37\%) were the most predominant. 
The following studies utilized different description methods in the analysis process. Skubiszewska et al. [19] presented their results using a division into independent and dependent patients in performing activities of daily living. The results in the ADL scale revealed $32 \%$ dependent respondents ( $0-2$ points) - (26\% women and $6 \%$ women), partly dependent (3-4 pints) - 37\% (33\% women and $4 \%$ men) and fully independent (5-6 points) - 20\% (10\% women and $10 \%$ men). Staszczak-Gawełda [20] used two different measure methods for the presentation of both scales. For the ADL scale, the percentage of patients who could perform 6 basic activities of daily living whereas for the IADL scale was used, applying the mean value.

During the review of foreign publications, including the article by Kingston et al. [21], the authors of the presented study noted the use of logistic regression analysis providing information on the quotient of chances for independence in performing the activities included in the ADL and IADL scales (joined into one scale), in a group of female and male individuals. The biggest difficulties were reported with cutting nails and the smallest with eating meals. A study [22] conducted in the Netherlands on a group of 594 patients aged $85+$ showed that in multi-disease patients the median value in the ADL scale amounted to 11 points, while Swedish research [23] revealed that in $51 \%$ of the persons studied aged $87-93$ years, there was a decrease in ADL results within three years.

The over-representation of Polish articles resulted from one of the criteria: open access to full article texts. This is an important criterion in Evidence-Based Medicine and Evidence- Based Nursing Practice. Open access to scientific articles plays a special role in popularizing EBM and EBNP in the Polish healthcare system.

The characteristics of the included studies is presented in Table 1, ordered by year of publication.

Table 1. Characteristics of studies using ADL and/or IADL [own elaboration]

\begin{tabular}{|c|c|c|c|c|c|}
\hline$\frac{0}{z}$ & 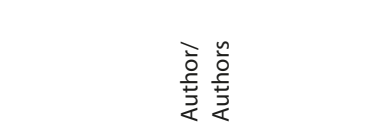 & 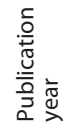 & 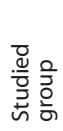 & $\overrightarrow{\mathrm{Q}}$ & 它 \\
\hline 1. & Violetta Jachimowicz, et al. [14] & 2009 & 18 & $5.5 \pm 0.7$ & $4.3 \pm 2.0$ \\
\hline 2. & Elżbieta Kozak-Szkopek, et al. [15] & 2009 & 22 & 5.81 & 24.5 \\
\hline 3. & Yvonne M. Drewes, et al. [22] & 2011 & 594 & $\mathrm{Me}=11$ & - \\
\hline 4. & Åsa Enkvist, et al. [23] & 2012 & 681 & $\%$ & - \\
\hline 5. & Andrew Kingston, et al. [21] & 2012 & 839 & OR & OR \\
\hline 6. & Izabela Staszczak-Gawełda, et al. [20] & 2013 & 127 & $\%$ & 18.5 \\
\hline 7. & Agnieszka Skubiszewska, et al. [19] & 2014 & 89 & $\%$ & - \\
\hline 8. & Grzegorz Puzio, et al. [18] & 2014 & 114 & $\mathrm{Me}-5$ & $\mathrm{Me}-18$ \\
\hline 9. & Małgorzata Mossakowska, et al. [16] & 2014 & 340 & 3.0 & 11.5 \\
\hline 10. & Monika Biercewicz, et al. [17] & 2015 & 127 & 4.89 & - \\
\hline
\end{tabular}

\section{DISCUSSION}

Assessment of independence and fitness of elderly persons in the area of basic and complex activities of daily living provides information on the quality of life of senior individuals. This enables designing and implementing effective solutions towards the optimization of living conditions of the group of the elderly. The data described above are valuable both for health service workers and for informal caretakers of elderly persons.

In the conducted research processes the authors used diverse analysis methods of the ADL and IADL scales, and applied statistical description using measures of central tendency and location, as well as structure of interest rates. However, such a demonstration of the obtained results impedes the acquisition of reliable knowledge and comparison of the assessment of basic and complex activities of daily living in the studied group.

Although in the Katz scale, which is considered the prototype of scales, the scoring is in the range of $0-6$ points, the authors of some of the publications mentioned in this the presented, based their research on different methodologies. Drewes [22] used a 9-36 score in his study. Every activity could be scored in a four-point scale where 1 represents full independence and 4 full dependence. The difference in the scale was not only reflected in the scoring, but also in the vector of changes. In the original scale, along with an increase in the points, the level of fitness increased, while in the analyzed example from the Netherlands, it decreased.

Review of the literature on the IADL scale resulted in similar doubts. The Lewton scale, considered as original, is scored in the range 8-24 points, and comprises 8 aspects. Along with an increase in the score, the fitness in complex activities of daily living is lower. The outcomes presented by Kozak-Szkopek [15] suggest the use of a scale extended by additional questions, which allows modification of the scale to the range between 9-27 points. Kingston [21] in his own research proposed presentation of results as joined scales of ADL and IADL, which aimed at a more precise assessment of activities of daily living.

Not all the studies were based on analysis of the present state but sometimes on many years' research. An example of this approach is the study by Enkvist et al. [23], which presented an analysis of the coefficient of variation within basic activities of daily living. Another difficulty in understanding the presented data, in many cases twas he lack of a comprehensive description of methodology.

Thus, analysis of research data used for comparing functional independence of senior persons on the basis of $\mathrm{ADL}$ and IADL is difficult due to the presented discrepancies, which may be confusing for researchers studying this area. Therefore, standardization of scales would significantly increase the effectiveness of studies in this field and would allow for a comprehensive geriatric assessment.

\section{CONCLUSIONS}

1. The use of different methodologies for assessing functional fitness of elderly individuals makes it difficult to interpret, compare and practically apply the outcomes.

2. Standardization of research methods used for assessment of basic and complex daily living activities in $80+$ persons would enable comparison of the obtained data from an interdisciplinary perspective.

\section{Acknowledgement}

The authors express their thanks to the Pomeranian Medical University in Szczecin, Poland, for providing funds for the performance of this systematic review. 


\section{REFERENCES}

1. Portret generacji 50+ w Polsce i w Europie. Wyniki badania zdrowia starzenia się i przechodzenia na emeryturę w Europie (SHARE) [Portrait of 50+ generation in Poland and in Europe. Results of health, aging and retirement in Europe (SHARE)]. Warszawa: Instytut Badań Edukacyjnych; 2014.

2. ec.europa.eu [homepage on the Internet] Policy - European Commission. https://ec.europa.eu/health/population_groups/policy_ en (access: 2017.06.02).

3. Prognoza ludności Unii Europejskiej 2008-2060 [Forecast of the population of the European Union 2008-2060]. EUROSTAT 2008.

4. Cybulski M, Cybulski Ł, Krajewska-Kułak E, et al. Ocena opieki geriatrycznej przez osoby w podeszłym wieku w wybranych krajach Europy Środkowo-Wschodniej [Assessment of geriatric care by the elderly in selected Central and Eastern European countries]. Gerontol Pol. 2016; 24: 269-277.

5. Żołędowski C. Starzenie się ludności - Polska na tle Unii Europejskiej [Aging population - Poland against the background of the European Union]. Problemy Polityki Społecznej. Studia i Dyskusje. 2012; 17: 29-43.

6. ec.europa.eu [homepage on the Internet] Statystyki dotyczące ludności na poziomie regionalnym [Regional population statistics]. http:// ec.europa.eu/eurostat/statistics-explained/index.php/Population statistics_at_regional_level/pl (access: 2017.06.11).

7. Zaidi A. Features and challenges of population ageing: the European perspective. Vienna. European Centre for Social Welfare Policy and Research. 2008 [cited 2017 Jun 14]; 49. http://www.euro.centre.org/ data/1204800003_27721.pdf.

8. Plaszewska-Żywko L, Brzuzan P, Malinowska-Lipień I, et al. Sprawność funkcjonalna u osób w wieku podeszłym w domach pomocy społecznej [Functional efficiency in the elderly in social welfare homes]. Probl Hig Epidemiol. 2008; 89(1): 62-66.

9. Szarota Z. Gerontologia społeczna i oświatowa [Social and educational Gerontology]. Kraków: Wyd. Naukowe Akademii Pedagogicznej; 2004

10. Wizner B, Skalska A, Klich-Rączka A, Piotrowicz K, Grodzicki T. Ocena stanu funkcjonalnego u osób w starszym wieku [Assessment of functional status in elderly] [w:] Aspekty medyczne, psychologiczne, socjologiczne i ekonomiczne starzenia się ludzi w Polsce [Medical, psychological, sociological and economic aspects of aging in Poland] (red.) Mossakowska M, Więcek A, Błędowski P. Poznań: Termedia; 2012 .

11. Graf C. The Lawton instrumental activities of daily living scale. Am J Nurs. 2008; 108(4): 52-62.

12. Lawton MP, Brody EM. Assessment of older people: self-maintaining and instrumental activities of daily living. Gerontologist. 1969; 9(3): 179-86.
13. Michałkiewicz H, Wróbel J. Całościowa ocena geriatryczna - narzędzie ważne również dla fizjoterapeutów [Global geriatric assessment - a tool important for physiotherapists as well]. Zamojskie Studia i Materiały 2012; 1(35): 91-96.

14. Jachimowicz V, Kostka T. Ocena poczucia własnej skuteczności u pensjonariuszy Domu Pomocy Społecznej [Evaluation of self-efficacy in the residents of the Social Welfare Home]. Gerontol Pol. 2009; 17(1): 23-31.

15. Kozak-Szkopek E, Galus K. Wpływ rehabilitacji ruchowej na sprawność psychofizyczną osób w podeszłym wieku [Impact of physical rehabilitation on psychophysical fitness of the elderly]. Gerontol Pol. 2009; 17(2): 79-84.

16. Mossakowska M, Broczek K, Wieczorowska-Tobis K, et al. Cognitive Performance and Functional Status Are the Major Factors Predicting Survival of Centenarians in Poland. J Gerontol A Biol Sci Med Sci. 2014; 69(10): 1269-1275.

17. Biercewicz M, Kędziora-Kornatowska K. Częstotliwość występowania chorób układu nerwowego w populacji osób powyżej 65 roku życia [The Incidence Rate of Nervous System Disorders in Patients Above the Age of 65]. JNNN. 2015; 4(3): 96-101.

18. Puzio G, Stopa A, Szczygielska-Babiuch A, et al. Ocena podstawowych i złożonych czynności życia codziennego pacjentów geriatrycznych po zabiegu endoprotezoplastyki stawu biodrowego [Evaluation of basic and complex activities of everyday life of geriatric patients after hip replacement surgery]. Postępy Rehabil. 2014; 4: 13-20.

19. Skubiszewska A, Wodzyńska K, Szybalska A, et al. Ocena sprawności funkcjonalnej warszawskich stulatków w zakresie podstawowych czynności życia codziennego - wyniki wstępne [Evaluation of functional skills of Warsaw centenarians in basic everyday activities - preliminary results]. Gerontol Pol. 2014; 3: 151-155.

20. Staszczak-Gawełda I, Szczygielska-Babiuch A, Puzio G, et al. Ocena sprawności funkcjonalnej osób starszych z lekkim otępieniem [Functional assessment of elderly patients with mild dementia]. Gerontol Pol. 2013; 4: 127-132.

21. Kingston A, Collerton J, Davies K, et al. Losing the Ability in Activities of Daily Living in theOldest Old: A Hierarchic Disability Scale from the Newcastle 85+ Study. PLoS One. 2012; 7(2): e31665.

22. Drewes YM, Den Elzen WPJ, Mooijaart SP, et al. The effect of cognitive impairment on thepredictive value of multimorbidity forthe increase in disability in the oldest old:the Leiden 85-plus Study. Age Ageing 2011; 40: 352-357.

23. Enkvista A, Ekström H, Elmståhl S. Associations between functional ability and life satisfaction in the oldest old: results from the longitudinal population study Good Aging in Skåne. Clin Interv Aging. 2012; 7: 313-320. 